Portland State University

PDXScholar

Summer 2021

\title{
The Effective Opening: Nonviolent Movements and How They Can Help to Enforce International Law Pertaining to Human Rights
}

Emmalyn A. Dewing

Portland State University

Follow this and additional works at: https://pdxscholar.library.pdx.edu/honorstheses

Part of the Human Rights Law Commons, and the Peace and Conflict Studies Commons Let us know how access to this document benefits you.

\section{Recommended Citation}

Dewing, Emmalyn A., "The Effective Opening: Nonviolent Movements and How They Can Help to Enforce International Law Pertaining to Human Rights" (2021). University Honors Theses. Paper 1128.

https://doi.org/10.15760/honors.1159

This Thesis is brought to you for free and open access. It has been accepted for inclusion in University Honors Theses by an authorized administrator of PDXScholar. Please contact us if we can make this document more accessible: pdxscholar@pdx.edu. 
The Effective Opening: Nonviolent Movements and How They Can Help to Enforce International Law Pertaining to Human Rights

\author{
by \\ Emmalyn A Dewing
}
An undergraduate honors thesis submitted in partial fulfillment of the requirements for the degree of
Bachelor of Arts
in
University Honors
and
Conflict Resolution

Thesis Adviser

Tom Hastings

Portland State University 


\begin{abstract}
This thesis paper will examine the following question: How can nonviolent movements create enough pressure on human rights-abusing powers so that the enforcement of international law pertaining to human rights is more viable? Through the lens of this question, the paper will argue that one of the most effective ways to fully enforce international law pertaining to human rights is through the success of nonviolent movements whose goals align with it. This paper will further briefly argue that these movements can be helped by the international community through external support in the form of training and advice. To support this argument this paper will break down nonviolent case studies from Serbia, Liberia, and Tunisia to demonstrate that international law pertaining to human rights can be, and already is being, enforced through these types of movements. Finally, this paper will give recommendations a) to nonviolent movements, governments, transnational organizations, and supranational organizations; b) for the more effective enforcement of international law pertaining to human rights; and c) to those engaged in future research.
\end{abstract}




\section{Introduction}

International law is a fickle thing - especially in regards to human rights abuses - that, for the most part, tends to be unenforceable. When it comes to the enforcement of international law pertaining to human rights there are many different institutions, declarations, and treaties ${ }^{1}$ that are set up to enforce the five main types of international law pertaining to human rights, which are: International Humanitarian Law (IHL), International Human Rights Law (IHRL), International Refugee Law (IRL), International Criminal Law (ICL), and International Disaster Response Laws, Rules, and Principles (IDRL) (Haider, 2013, pp. 7-10). However, despite the lofty goals of institutions such as the UN, the efforts by the UN Office of the High Commissioner on Human Rights, the extensive international laws in place pertaining to human rights, and the many treaties that are supposed to create the foundation to advance the enforcement of human rights, this system does not work nearly well enough. This thesis will use literature from the fields of international law as it pertains to human rights and conflict resolution as it pertains to nonviolent movements to argue that simply pursuing the enforcement of international human rights through the law is at times inadequate. ${ }^{2}$ It will further hypothesize that given current international structures, the enforcement of international law pertaining to human rights is much more likely to be successful when paired with localized nonviolent movements seeking the same ends. This hypothesis will be tested against three different nonviolent movements: the Otpor Movement in Serbia, the Women of Liberia Mass Action for Peace movement, and the Jasmine Revolution in Tunisia.

\footnotetext{
${ }^{1}$ For more information refer to OHCHR International Human Rights Law, n.d., n.p. (see references).

${ }^{2}$ An example of this would be the absent radical reform of the United Nations and its Security Council in particular that claims to use sanctions to enforce human rights and yet fails to issue sanctions against any of the permanent members of the Council, even when those members clearly violate human rights (UN Sanctions Security Council, n.d., n.p.).
} 


\section{What is International Law with Regards to Human Rights?}

International laws pertaining to human rights are the ratified declarations, treaties, and institutions whose purpose is to enforce universally agreed-upon human rights when they are abused. International law pertaining to human rights originated with the Paris Peace Conference in 1919. This conference culminated with the League of Nations and the Treaty of Versailles. Arguably, the three most important points regarding the creation of human rights in law today were from the Treaty of Versailles. These were: The International Labor Organization (ILO), the first articulation of war crimes as agreed upon by most of the international community, and the "international resolve" within the Treaty of Versailles to hold those who commit war crimes accountable (Stratton, 2020, Chapter 1). Nevertheless, this initial effort could not prevent the horrific human rights abuses committed during World War II.

Due to the human rights abuses committed during World War I and II three main changes took place in the international community regarding human rights. The establishment of the United Nations (UN) and the International Court of Justice (ICJ) in 1945 resulted in a strengthened international commitment to human rights. The UN Charter includes clauses promoting nation-state collaboration concerning "respect for human rights and for fundamental freedoms for all without distinction as to race, sex, language, or religion" (UN, n.d., Charter of the United Nations). Simultaneously, the ICJ was created in order "to settle, in accordance with international law, legal disputes submitted to it by States and to give advisory opinions on legal questions referred to it by authorized United Nations organs and specialized agencies" (UN, n.d., International Court of Justice). The third change that took place was the creation and ratification of the Universal Declaration of Human Rights (UDHR) in 1948. This declaration created "a common standard of achievements for all peoples and all nations" regarding "fundamental 
human rights" that should be universally protected (UN, Universal Declaration of Human

Rights). However, even with these laws, treaties, and other legal instruments, human rights abuses remain common. Recognizing this, the International Criminal Court (ICC) was formed in 2002 in Rome as a sister court to the ICJ. The ICC "investigates and, where warranted, tries individuals charged with the gravest crimes of concern to the international community: genocide, war crimes, crimes against humanity, and the crime of aggression" (ICC, n.d.). Additionally, parties other than nation-states are permitted to file complaints with the ICC. Despite these various institutions and declarations, the international community is still unable to adequately protect human rights in all times and places.

\section{Why is There So Much Trouble with Enforcement?}

As Douglas Donoho explains, the enforcement of laws pertaining to human rights was "designed for failure" (Donoho, 2006, pg. 5). According to Donoho, this is primarily because it relies almost entirely on the "dubious premise that governments will faithfully implement international human rights standards within their own domestic systems," and secondarily, because the international human rights institutions put in place to bolster government compliance with human rights standards have little actual enforcement power (Donoho, 2006, pg. 5). Unfortunately, these institutions are "generally limited to monitoring state compliance and promoting adherence to underdeveloped international standards through dialogue, condemnation, and moral suasion" (Donoho, 2006, pg. 5). While these approaches have achieved some success, they are at times ineffective at protecting human rights, especially when it comes to powerful governments and dignitaries such as permanent members of the UN security council, countries that have not signed certain treaties and agreements, and governments that simply do not care enough about sanctions or condemnations to change their ways. In conclusion, while there is 
some enforcement of international law pertaining to human rights, it is, at times ineffective and therefore allows for countries and dignitaries that have ratified treaties, as well as countries that have not, to get away with violating human rights. However, an analysis of cases in which the enforcement of human rights laws has been successful reveals an interesting and little studied pattern: the involvement and success of grassroots nonviolent movements allows for better enforcement of international law pertaining to human rights.

\section{Literature Review}

In this examination of the intersection between the literary fields of international law pertaining to human rights and nonviolent movements, it is important to first recognize that there is no current literature in either field that addresses the hypothesis of this paper. Due to this, this literature review will be breaking down the literature into two main sections. These two main sections will be: (1) a review of the literature that involves international law regarding human rights and its enforcement and (2) a review of the literature regarding nonviolent movements, how they work, and what types of external assistance can help them. This literature review will conclude by discussing the downfalls of the separation of these two types of literature.

Furthermore, this paper will not be arguing for a change in efforts or approaches of nonviolent movements, but rather the recognition and further academic study of the opportunity that nonviolent movements create for better enforcement of international law pertaining to human rights. This recognition should, in turn, allow for practitioners in the field of international law pertaining to human rights to recognize when an opportunity for successful enforcement has been created by a grassroots nonviolent movement and to further consider it as a tool to bolster enforcement. 


\section{International Law Pertaining to Human Rights}

Because international law is such a wide-ranging field of study, this literature review will be discussing writings having to do specifically with human rights law and its enforcement. Examination of literature focusing on international law pertaining to human rights reveals two central arguments. The first is the view that the expectations regarding the enforcement of international law pertaining to human rights are unrealistically high. However, through my research I found only one author, Harold Hongu Koh, who argued this stance. The second argument - and the one that I found to be much more prevalent throughout the field - asserted that the actual enforcement of international law pertaining to human rights does not always work due to how it is structured. The central authors who argue this point are Douglas Donoho and Terry Collingsworth.

In this field of study, there are few who argue that international law pertaining to human rights is completely enforceable. However, in his lecture entitled "How Is International Human Rights Law Enforced?" (1998), Koh presents a noteworthy argument. While this lecture has the downside of being published twenty-three years ago, it presents the view that international law pertaining to human rights should be regarded just like any other type of law. Koh argued this by asserting that just because not every single human right is enforced does not mean that human rights law itself is unenforceable. In comparing the imperfect enforcement of international law pertaining to human rights to the imperfect enforcement of parking laws, Koh argues that we cannot expect international law pertaining to human rights to be perfectly enforced. However, there is one main flaw with this argument: parking laws, in the long run, are fairly minor while human rights abuses are not. If a person decides to go against the law and park somewhere they are not supposed to, the most harm they are likely doing is blocking a vehicle that needs to park 
there. However, if a person or government decides to ignore the laws, articles, and treaties surrounding human rights they are going against agreed-upon rights belonging to every human being and most likely harming an actual human being in the process.

In contrast to Koh's argument, there is substantial literature that argues that there is a lack of enforcement regarding international law pertaining to human rights. On this side of the discussion, scholars argue that the field of international law pertaining to human rights is not fully enforceable because the enforcement mechanisms that are currently in place face a number of limitations. As Douglas Donoho explains in his article, "Human Rights Enforcement in the Twenty-First Century," the system of human rights is "after all, a system designed with significantly limited enforcement capacity" because, as discussed above, it was designed on the premise that governments will voluntarily implement international human rights standards in their countries (Donoho, 2006, pg. 5). Donoho goes on further to make three points about how this system was designed for failure. These are, the fact that it was designed to rely on voluntary compliance, it created an anemic network of international mechanisms and institutions, and he only tools international human rights institutions (IHRIs) are empowered with in their efforts to enforce human rights law are "dialogue, condemnation, and moral suasion" to try to enforce human rights law (Donoho, 2006, pg. 5). Donoho's argument is further proved by Terry Collingsworth in his article "The Key Human Rights Challenge: Developing Enforcement Mechanisms". While published four years earlier in 2002, Collingsworth's writing supports Donoho's later claims by stating that any new standards that are set in the field of international law would just join "a stack of well-intentioned human rights conventions and resolutions that remain basically unenforceable" (Collingsworth, 2002, pg.183). These claims are supported by the fact that despite international laws pertaining to human rights being around for over 76 years, 
there are still some issues when it comes to enforcing them. The analysis of the writers above suggests a generally ineffective system of enforcement of human rights law, which this paper will argue becomes more effective when paired with nonviolent movements. Furthermore, because of the issues still surrounding the enforcement of this form of international law, the formation and success of nonviolent movements is that much more important.

\section{Nonviolent Movements}

Nonviolent movements have been around for much longer than international law pertaining to human rights. Research has been done on how nonviolent movements work, the strategies that work best, and the most effective external support in regards to helping nonviolent movements meet their goals and stay nonviolent. Despite this, there is a significant lack of research on how nonviolent movements can help enforce international law pertaining to human rights in times of conflict. However, the research that has been done in the field of nonviolence creates a strong foundation for future research in this area. This foundation is made of (1) studies surrounding nonviolent movements and how they work and (2) research that looks at the types of external support that is most helpful in regards to supporting nonviolent movements.

\section{How Nonviolent Movements Work}

To fully understand how important nonviolent movements are to the enforcement of international law pertaining to human rights one must first understand how nonviolent movements are successful and how they create change. This idea is addressed by many different scholars in many different literary works. From the founder of the field, Gene Sharp, to two thinkers at the forefront of the field, Erica Chenoweth and Maria Stephan, nonviolent movements, how they work, and the reasons and attributes that determine their success have been studied and written about in detail. According to Erica Chenoweth's new book Civil 
Resistance: What Everyone Needs to Know, civil resistance is defined "as a form of struggle in which unarmed people coordinate in a variety of actions - such as strikes, protests, sit-ins, boycotts, stay-away demonstrations, noncooperation, and lots of other tactics - to build power and force change" (Chenoweth, 2021, pg. 28). This is one of the most comprehensive definitions of nonviolent movements to date. It is based on the twin premises that "oppressive systems tend to be much more fragile than they appear" and that nonviolent movements are much more effective than any other type of resistance (Chenoweth, 2021, pg. 29).

According to the article "Preventing Mass Atrocities: From a Responsibility to Protect (RtoP) to a Right to Assist (RtoA)" by Peter Ackerman and Hardy Merriman, research done by Chenoweth and Maria Stephan proves that nonviolent campaigns are both more likely to succeed compared to violent campaigns as well as less likely to result in mass killings. This research regarding the success of nonviolent movements (shown in Graph 1) shows that out of 323 campaigns actively seeking maximalist ${ }^{3}$ objectives between 1900 and 2006, nonviolent campaigns succeeded in their goals $53 \%$ of the time, while violent campaigns only succeeded in their goals only $26 \%$ of the time (Ackerman, 2019, pg. 6). The opposite is true when looking at the failure of campaigns to achieve their objectives: violent campaigns failed approximately $60 \%$ of the time while nonviolent campaigns only failed around 20\% of the time (Ackerman, 2019, pg. 6).

\footnotetext{
${ }^{3}$ A maximalist campaign is a campaign that has revolutionary goals such as the "(1) overthrow of an incumbent national government; or (2) territorial and national independence through secession or expulsion of a colonial power or foreign military occupation" (Chenoweth \& Stephan, 2021, pg. 6).
} 


\section{Graph 1}

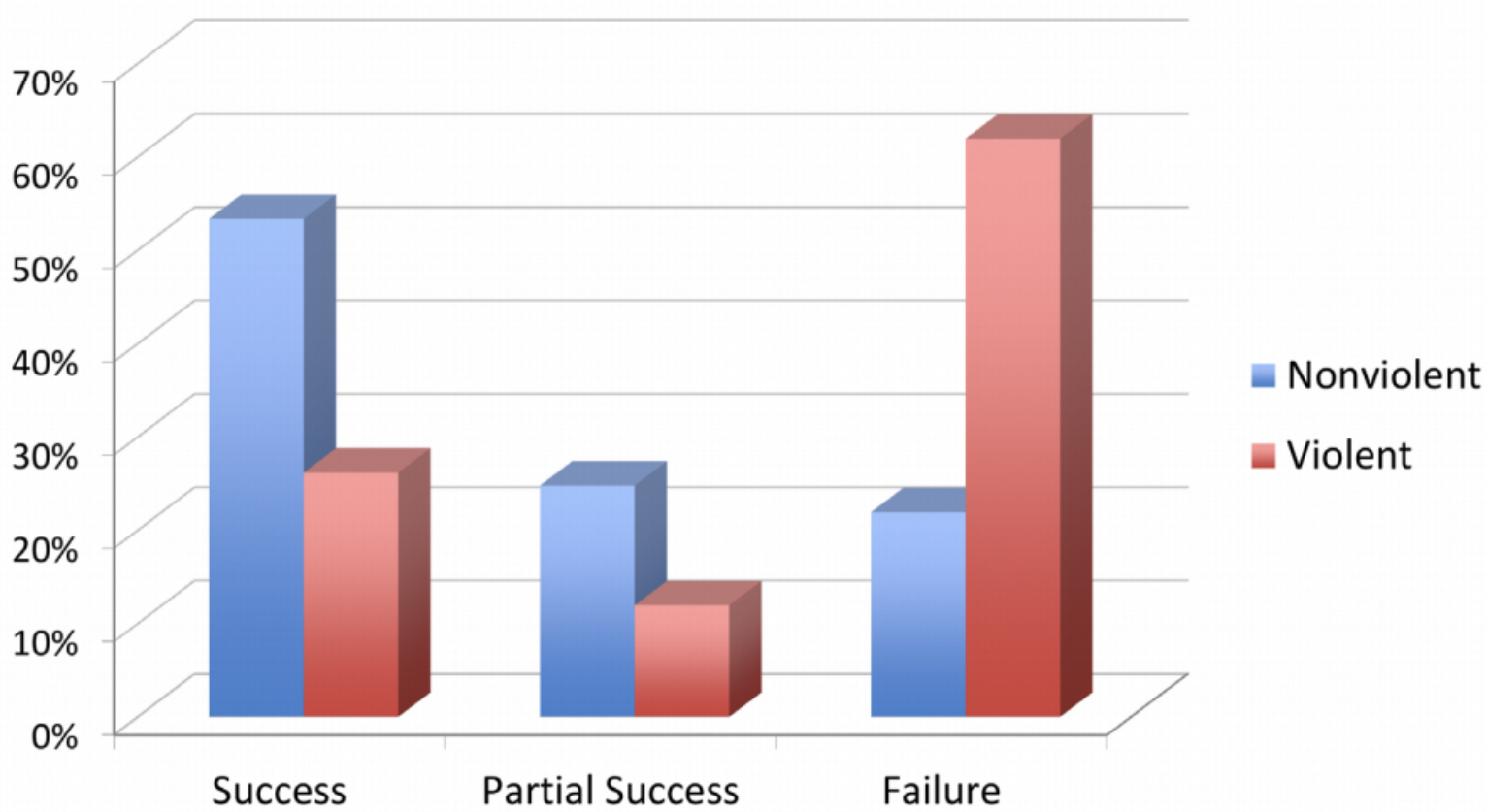

Source: Ackerman, Peter, and Hardy Merriman. (2019). Preventing Mass Atrocities: From a Responsibility to Protect (RtoP) to a Right to Assist (RtoA) Campaigns of Civil Resistance.

This success is attributed to four main reasons. The first is "the scale and range of popular participation" following the $3.5 \%$ percent rule (Chenoweth, 2021, pg. 82). This rule states that as long as a nonviolent movement has active participation of at least $3.5 \%$ of the population, it will succeed in its goals. The second reason for the success of nonviolent movements is "a movement's ability to shift the loyalties of people within the adversary's pillars of support" (Chenoweth, 2021, pg. 85). This reasoning also follows the 3.5\% participation rule because when enough of the population is participating in a nonviolent movement the pillars that hold up a seemingly strong government start to break down. Finally, the third and fourth reasons for the success of nonviolent movements are a) their ability to shift their methods between a "wide variety of tactics" - allowing for nonviolent movements to respond to different reactions by the power they are going up against in safe and effective ways - and b) their ability to 
maintain discipline in the face of repression (Chenoweth, 2021, pgs. $87 \&$ 88). However, both of these last reasons for the success of nonviolent movements are often rooted in training. This makes external support that supplies training conducive to the success and safety of nonviolent movements.

External Support ${ }^{4}$

Current releases of scholarly literature on external support to nonviolent resistance supports one main theme: depending how it is given, external support can be incredibly helpful for nonviolent campaigns to have as a resource or it can be the very downfall of the nonviolent movement. For instance, external support in the form of training has proven to increase participation, lower fatalities, and increase the likelihood of defections whereas support such as assisting armed actors or repressive regimes will undermine the effectiveness of nonviolent movements. According to Peter Ackerman and Hardy Merriman, one of the most important components of external support for nonviolent movements is the "public education about civil resistance" that the people have regarding the successes and failures of different types of movements (Ackerman and Merriman, 2019, pg. 11). This is because people "tend to engage in the form of resistance that seems most powerful to them" and "too frequently violent insurrection is perceived as their only viable option" (Ackerman and Merriman, 2019, pg.12). Erica Chenoweth and Maria Stephan support this finding in their recent monograph studying nonviolent movements between the years 2000 and 2013. Just like Ackerman and Merriman, Chenoweth and Stephan concluded that external support by way of training during the pre- and

\footnotetext{
${ }^{4}$ As a precursor to this section I would like to state that while it is important to discuss the current literature surrounding the failures and successes of external support for nonviolent movements, it is not essential to the argument of this paper. As the review of the literature below shows external support, while being important, is not essential to the success of nonviolent movements. Therefore, it is not essential that a nonviolent movement have external support to enforce international law pertaining to human rights. However, as will be discussed in recommendations, it is an important piece for outside organizations to be aware of so as not to affect the nonviolent movement negatively.
} 
peak-campaign periods is incredibly important for establishing consistently positive impacts on the campaign. These impacts include but are not limited to "higher participation rates [and] lower campaign fatalities" during the pre-campaign period as well as "higher probabilities of security force defections," "increase in participation size," and a higher chance of goal success during the peak-campaign period (shown in Figure 1 below) (Chenoweth, 2021, pgs. $65 \& 66$ ).

Through the arguments made by all four of these esteemed scholars in the conflict resolution field, it becomes clear that external support, when applied correctly, can be useful in both keeping nonviolent movements nonviolent and helping them succeed. This argument is further upheld by the reasoning given in each monograph.

\section{Figure 1}

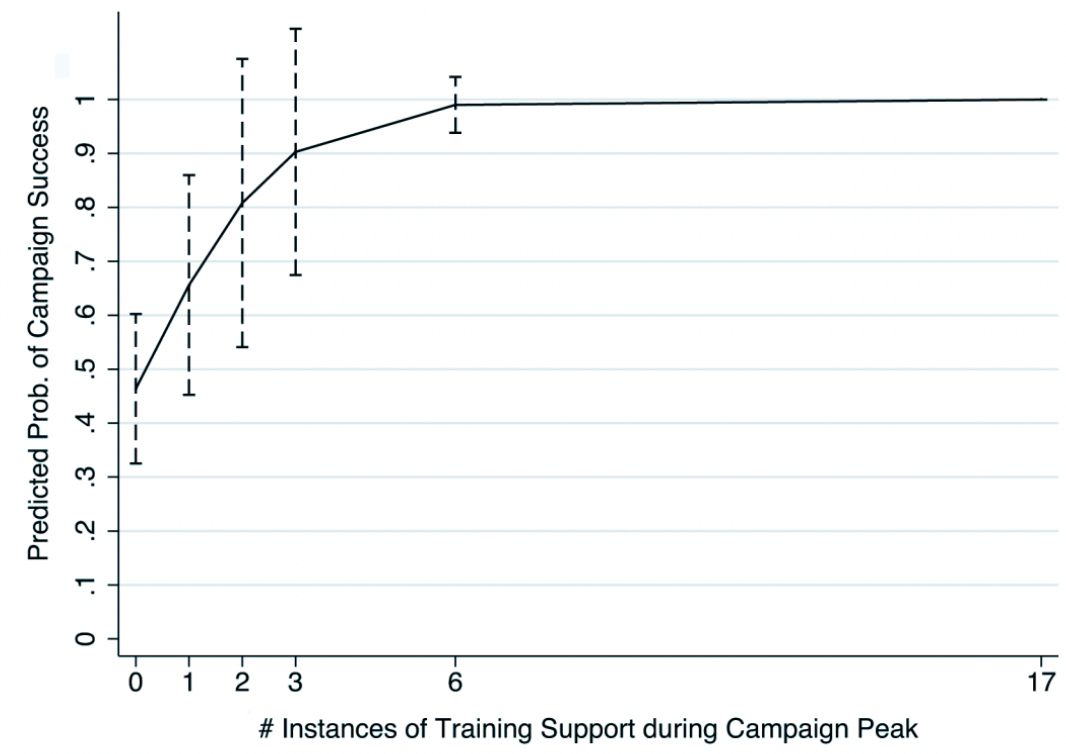

FIGURE 1. Correlation between Training Support during Campaign Peak and Campaign Success Marginal effects of training support during campaign's peak on campaign success with $95 \%$ confidence intervals. $p<.001$. Based on a logistic regression controlling for the logged number of campaign participants with robust standard errors clustered around location. $n=68$

Source: Chenoweth, E., \& Stephan, M. J. (2021). The Role of External Support in Nonviolent Campaigns: Poisoned Chalice or Holy Grail? ICNC. 
Ackerman and Merriman argue one specific type of external assistance has proven a failure over the years: the Right to Protect (RtoP). They argue that the RtoP, though a good idea on paper, was not an attainable goal in the long run due to the fact that since "its original adoption to the present" it had "been damaged and its fundamental weakness revealed" (Ackerman \& Merriman, 2019, pg. 3). However, Ackerman and Merriman also argue that "the risk of mass atrocities is too stark for debate to remain stuck in this conundrum" and to this end suggest an alternative form of external support in the form of the Right to Assist (RtoA) (Ackerman \& Merriman, 2019, pg. 3). The RtoA "is based on the premise that the risk of atrocities rises dramatically when two or more sides engage in violent conflict" (Ackerman \& Merriman, 2019, pg. 3). Therefore, "when, not if" a population rises up and resists an oppressive government there is more likely to be fewer mass atrocities if that population has had prior training and education about nonviolence (Ackerman \& Merriman, 2019, pg. 4). The argument made by Ackerman and Merriman is analytically strong, but it has yet to be proven through academic analysis of the real life impact of the RtoA. This is where Chenoweth and Stephan come in with specific research on how different types of external support have affected nonviolent movements in the past.

While Chenoweth and Stephan agree with Ackerman and Merriman that one of the most important forms of assistance to nonviolent movements is training and education about nonviolence they also argue against certain types of external support that: (1) does not recognize "the strategic capacity of local actors," (2) creates support for "the regime's security apparatus" which can create a power imbalance and/or withdrawal of support - and (3) leads to less participation through actions such as direct financial funding (Chenoweth \& Stephan, 2021, pgs. $74 \& 78)$. Chenoweth and Stephan argue that it is important for external supporters to recognize 
how the different types of support given can help or harm nonviolent movements. Looking at both of these arguments it is clear that external assistance, especially in the form of training, is important to helping populations choose nonviolence and then stay nonviolent. The choice of nonviolence as well as the ability to stay nonviolent is important to the success of civil resistance movements. This success of nonviolent movements is then important to both helping to stop any further human rights abuses and creating an opening to allow for the better enforcement of human rights internationally.

\section{Concluding of the Literature Review}

The biggest downfall with all of these arguments is that they comment on issues that, while true, are not areas that people outside of the conflict resolution or international law field pay attention to. This is where the argument of this thesis falls into place. By creating an interdisciplinary argument between these two fields there is a greater chance that common ground will be found and international law pertaining to human rights will be, overall, more enforceable.

\section{Nonviolent Movement Examples}

For this section, I have drawn from many different sources detailing the events of three different nonviolent movements. I have found through my study of this type of nonviolent movement that more effective enforcement of human rights internationally is created when nonviolent movements are successful. This finding will be shown through three different reasons that are prevalent in the cases of Serbia, Liberia, and Tunisia. These reasons are: (1) the events and goals of each movement, (2) the timing of when the major human rights abuse powers are held accountable, and (3) the direction a country takes after a successful nonviolent movement. Now, this does not mean that nonviolence will work every single time it is tried or that this is the 
only way to enforce international law pertaining to human rights. However, the use of nonviolent movements - especially ones that have had their success rate boosted by correct external assistance - will help to bolster the current methods being used to enforce human rights when abuses occur. In each of the three cases, this thesis will argue that the protection of human rights against the abusing powers was ultimately achieved in large part due to the efforts of these nonviolent movements.

\section{The Otpor Movement (1998-2000)}

The first case study supporting the difficulty of enforcement of human rights and the value of nonviolent resistance can be shown through the crimes against humanity that were committed by former Serbian president Slobodan Milosevic in the late 1990s. This difficulty can be seen through three main points: (1) the initial reaction by the North Atlantic Treaty Organization (NATO) to these crimes, (2) the fact that it took a nonviolent civil resistance movement to oust Milosevic from the presidency, and finally (3) the tribunal charged with putting those who committed human rights abuses on trial during this period was created in 1993, but did not indict Milosevic until 1999 when he was almost out of power due to the success of the nonviolent movement.

In the 1990s Yugoslav Wars, Slobodan Milosevic, "also known as the bloodiest tyrant in Europe, the Butcher of the Balkans," committed atrocious crimes against humanity such as ethnic cleansing, concentration camps, unemployment, poverty, corruption, repression, and fear (York, 2002, 1:20; 1:39). A major example of these war crimes was the 1998 ethnic cleansing of Albanians in Kosovo. This ethnic cleansing outraged the West causing NATO to take action. However, despite international law being in place under the UN, the ICJ being up and running, the UDHR having been established, and the International Criminal Tribunal for the former 
Yugoslavia (ICTY) having been established, NATO's response to these horrific crimes was a "massive bombing campaign" to weaken Milosevic and force him to stop committing crimes against humanity (York, 2002, 2:13). The only thing this bombing campaign accomplished was the suffering of the Serbian people, which actually caused them to "rally around Milosevic," further cementing his power (York, 2002, 2:37). As the Director of the Balkans Peace Initiative, Daniel Sewer put it in the film Bring Down a Dictator

He didn't care how much damage his army suffered or his people suffered. What he cared about was his own hold on power. The bombing in the end clearly strengthened his hold on power in the short-term, it may have in the longer term undermined it, but the notion that he was going to worry about military damage is nonsense, he wasn't going to. But, I heard many many times in the State Department "he will only respond to force" $(2002,3: 03)$

The analysis that Milosevic will only respond to force actually proved to be true but not in the way the State Department was thinking and definitely not in the traditional sense. The force that proved able to pull Milosevic from power was nonviolent resistance. It was not actually until the formation of the student-led resistance movement, Otpor, that there seemed to be hope for the revival of democracy in Serbia.

Otpor was a student-led nonviolence resistance group in Serbia that operated in the late 1900s and early 2000s. Otpor's main goal was to nonviolently remove Serbian President Slobodan Milosevic. Otpor used training, networks of everyday people, protests, and humor to create and maintain a national nonviolent resistance movement that put pressure on Milosevic until he was forced to hold democratic elections in 2000 , elections that he ultimately lost. Milosevic was then put on trial for crimes against humanity in 2002, shortly after his ousting 
from power. Looking at this succession of events, it becomes clear that without the Otpor nonviolent movement, Milosevic may not have been ousted from power or tried by the ICTY. Breaking it down, the ICTY was first founded in 1993, however, Milosevic wasn't indicted by the ICTY until 1999 - this was after NATO cemented his power in Serbia further through their retaliation to the ethnic cleansing of Albanians in Kosovo. This means that NATO chose to use violent force even though there was already an UN-sanctioned tribunal for this specific conflict to try crimes against humanity. Because of this decision by NATO, it can be inferred that there was no belief that using the ICTY would work to stop Milosevic due to the lack of enforcement the tribunal held. Taking this analysis a step further Milosevic was not put on trial for his crimes until a grassroots nonviolence movement in the form of Otpor had forced Milosevic out of the presidency and therefore taken his power from him. Then and only then was the international community able to hold Milosevic accountable for the crimes he committed throughout the Yugoslav Wars.

\section{Women of Liberia Mass Action for Peace (2003-2006)}

The second case study of the enforcement of international law pertaining to human rights being assisted by nonviolent movements can be shown through the extensive human rights abuses that the people of Liberia lived through from 1989-2003, throughout the first and second Liberian Civil War. This failure of enforcement in Liberia, like Serbia, can be shown through three main points: (1) There was an attempt to secure peace in 1997 that failed to address human rights or keep the peace, (2) there were no further attempts after this failed attempt until after the Women of Liberia Mass Action for Peace movement got each side of the conflict to agree to peace talks, and (3) both the peace talks and the resulting peace agreement allowed for Charles Taylor to be indicted and tried for war crimes. 
The Liberian Civil War falls into two parts called The First and Second Liberian Civil Wars. The first of these two civil wars fell between the years of 1989-1997. There was a short-lived peace between the years of 1997 and 1999, which was when the civil war restarted and did not end until 2003. At this point it is important to mention that there was a peacekeeping attempt in 1990 when "a group of West African nations under the auspices of the Economic Community of West African States (ECOWAS) took the unprecedented step of sending a peacekeeping force into Monrovia [...] known as the Economic Community Cease-Fire Monitoring Group, (ECOMOG)" (Waging War to Keep the Peace: The ECOMOG Intervention and Human Rights, 1993, n.p.). However, while this peacekeeping force temporarily stopped the civil war it did not integrate "human rights protection and promotion into its activities" and therefore became "embroiled in a conflict with few immediate prospects for resolution" (Waging War to Keep the Peace: The ECOMOG Intervention and Human Rights, 1993, n.p.). This shortcoming resulted in the civil war restarting in 2000. Peace was finally achieved three years after this, as a direct result of the Women of Liberia Mass Action for Peace movement.

This nonviolent movement was a reaction to the resurgence of the 1989-1997 Liberian Civil War in 2000. During this time, Liberia was plagued with chaos and violence. The main parties of the civil war were President Charles Taylor and his military, the Liberians United for Reconciliation and Democracy (LURD), and in 2003 the Movement for Democracy in Liberia (MODEL). Both the LURD and the MODEL were warlord parties working to remove Taylor from power. However, the tactics used by all sides were those of violence and by 2002 an estimated 200,000 people had died. At the same time, this civil war was characterized by child soldiers who were forced to kill and take drugs at very young ages. This conflict was a fight for power; none of the sides were fighting for the actual civilians of the country. Soldiers from all 
sides of the war "burned villages, raped women, and recruited young boys to fight" (Navarro, 2010, n.p.). Human rights abuses at this time were an everyday thing. People barely had food or water, they lived in constant fear, and children were recruited to do unimaginable horrors. However, while there was an attempt to enforce international law pertaining to human rights through ECOWAS, it was not until the women of Liberia stood up for peace with a nonviolent movement and got both sides to agree to peace talks that the peace and in turn human rights were attainable.

The Women of Liberia Mass Action for Peace movement started with a woman named Leymah Gbowee. It started with a simple request that the women of hers and other Christian churches pray for peace. Shortly after this, a Muslim woman declared she would call on her Muslim sisters to join the blossoming movement. This led to the first religious joint nonviolent movement in the form of mass peaceful protests, declarations, sex strikes, marches, and vigils (Navarro, 2010, n.p.). Through these actions Liberian women got parties on both sides of the conflict to agree to peace talks in Accra, Ghana. However, the Liberian women's movement did not end here. Worried about the parties not feeling the need to reach a settlement, the movement raised money and sent some of the women to Ghana to keep pressure on the parties even while they were not allowed in the room. At this time "Taylor was indicted for war crimes by an international court in Sierra Leone" causing him to flee back to Liberia and leave the peace talks up to his delegates (Navarro, 2010, n.p.). Soon after "a full-scale war broke out in Monrovia even while the peace talks continued in Ghana" (Navarro, 2010, n.p.). This left Liberia once again in a state of war and chaos with the peace talks going nowhere because "these warlords, who slept in bushes before and who have never known good lives, some of them were living their dream life at the peace talks. It was almost like they were on vacation” (Reticker \& Disney, 
2008,). To combat all of this the women that were in Ghana sent for reinforcements. When the reinforcements showed up in Ghana the women surrounded the building and refused to let anyone out until an agreement was made. The peace talks finally finished successfully in 2004 with the Accra Comprehensive Peace Agreement. While the Liberian women's movement continued until the November 23, 2005 democratic election of the first female president, the importance of this case study is the fact that after approximately thirteen years of civil war in Liberia, it was a nonviolent movement and no other force that was able to stop the civil war by successfully pushing Liberia into a peaceful democracy.

\section{The Jasmine Revolution (2010)}

The final case study to be examined in this paper is the 2010 Jasmine Revolution in Tunisia. This nonviolent movement kickstarted the Arab Spring across the Middle East and North Africa Region (MENA). The Tunisian protests started after a 26-year-old street vendor, Mohammed Bouaziz, set himself on fire in protest against "the confiscation of his produce stand, his violent treatment at the hands of police officers, and the municipal office's refusal to hear his complaint" (Tedla, 2011, n.p.). This in turn set off large-scale protests across Tunisia by people voicing "frustration over police violence, poverty, high unemployment, and a lack of human rights" (Tedla, 2011, n.p.). The protests eventually called for and succeeded in ending President Zine Al-Abidine Ben Ali’s regime, ultimately moving Tunisia toward democracy.

Despite only being a week-long campaign, the Tunisian protest was successful in advancing the enforcement of human rights through nonviolence as well as in creating a democracy. Significant reasons for this include training, limited external interference, and previous "facilitated dialogues between secular and Islamist leaders" that built trust (Chenoweth $\&$ Stephan, 2021, pg. 42). Based on this information and the direction Tunisia took in the 
Jasmine Revolution follows most closely with the direction I believe can be taken to help the enforcement of international law pertaining to human rights in areas where this is difficult. This direction starts with external actors providing nonviolence training to civilians in countries so that when the time comes to start a movement of resistance against oppression and human rights abuses, the people of the country will know how to use a campaign of nonviolence to enhance the likelihood that their efforts will be successful.

\section{Case Studies Conclusions}

The case studies reviewed here show that, in each case, human rights were not enforced until after the successful implementation of a nonviolent movement. In the case of Serbia, Milosevic was not indicted for war crimes until Otpor's nonviolent movement had reached its climax even though the ICTY had already been implemented; in Liberia, no force, including that of ECOWAS, was able to stop the war and successfully promote peace until the women of Liberia stood up in nonviolent protest; and finally, in Tunisia, it was not until a nonviolent movement succeeded that the Tunisians finally established a democracy that did not abuse their human rights. While these case studies represent a small sampling, the pattern that they demonstrate is deserving of greater future examination. If more detailed research and analysis proves that the establishment and success of nonviolent movements aids in the enforcement of human rights, then this could provide a blueprint for much greater success in future efforts.

\section{$\underline{\text { Recommendations }}$}

This section will offer recommendations to nonviolent movements and the governments, transnational organizations, and supranational organizations that deal in the enforcement of international law pertaining to human rights. Finally, I will offer recommendations for future 
research. While some of these recommendations may show redundancy with earlier parts of this paper, this section is important to conclude the findings of this thesis and suggest future research.

\section{Nonviolent Movements}

I do not have much to recommend to nonviolent movements. This is based on my findings that the enforcement of human rights internationally is helped along by the successful implementation of nonviolent movements and how they are currently operating. Therefore, I believe that recommending any large changes would be deconstructive. I would, however, still like to recommend two minor thoughts that nonviolent movements should keep in mind when starting up. These are:

(1) Having a clear understanding their human rights and how to advocate for them

(2) Undergoing nonviolence training in some form to make sure that the movement stays nonviolent and that participants know how to respond to specific situations

\section{Governments, Transnational Organizations, and Supranational Organizations}

As Stephan and Chenoweth argue in their monograph "The Role of External Support in Nonviolent Campaigns: Poisoned Chalice or Holy Grail?", external support has not been proven to be either bad or good. That said, there are specific types of external support that best help nonviolent movements. The one that Chenoweth and Stephan pointed out as helping a nonviolent movement the most was training. Based on this and the argument of this thesis I recommend four things to governments, transnational organizations, and supranational organizations:

(1) Organizations and governments looking to support nonviolent movements should always ask the leaders and participants of the movement what they need instead of just basing assistance on assumptions. 
(2) If external aid is given, it should never be in the form of weapons or military might as that undermines the resistance movement and pushes it towards violence.

(3) Training on types of nonviolent action and the stages of nonviolent movements can and will help to keep nonviolent movements nonviolent, lower death rates, and raise the chance of success.

(4) Finally, a specific reform should be made to the UN Security Council to eliminate the permanent members of this council. By doing this, sanctions against human rights abusers that are currently somewhat immune to them due to their status as permanent members of this specific council will be more successful.

If these four recommendations are followed, I believe it would greatly increase the safety, effectiveness, and success of nonviolent movements. This would then allow for greater enforcement of international law pertaining to human rights.

\section{Enforcement of International Law Pertaining to Human Rights}

In terms of international law pertaining to human rights, I am not sure exactly what I would recommend. However, I do know what I would not recommend. I would not recommend stopping any attempts at enforcement instead of waiting for nonviolent movements to succeed because while human rights are not completely enforceable at the moment that does not mean that there is no enforcement at all. So, I would say my biggest recommendation for the enforcement of human rights law would be to recognize when a nonviolent movement has created an opening for enforcement and take it.

\section{Future Research}

When looking at future research I believe it would be advisable to compile data sets that will either concur or disprove the hypothesis argued in this thesis paper. At this moment the 
hypothesis of this paper cannot be proven in its entirety because there is no specific research to back it up. Therefore in terms of specific research, I believe it would be prudent to compile data sets on two types of nonviolent movements. The first would look at nonviolent movements that succeeded and whether international law pertaining to human rights was enforced in those cases while the second would look at nonviolent movements that did not succeed in their goals and what happened with international law in those cases. 


\section{References}

Ackerman, P., \& Merriman, H. (2019). Preventing Mass Atrocities: From a Responsibility to Protect (RtoP) to a Right to Assist (RtoA) Campaigns of Civil Resistance. International Center on Nonviolent Conflict.

Bringing Down a Dictator (English). (2002). ICNC. http://www.nonviolent-conflict.org/bringing-dictator-english/.

Chenoweth, E. (2021). Civil Resistance: What Everyone Needs to Know. Oxford University Press.

Chenoweth, E., \& Stephan, M. J. (2021). The Role of External Support in Nonviolent Campaigns: Poisoned Chalice or Holy Grail? ICNC. https://www.nonviolent-conflict.org/resource/icnc_monograph_external_support_poisone d_chalice_holy_grail/.

Collingsworth, T. (2002). The Key Human Rights Challenge: Developing Enforcement Mechanisms. Harv. Hum. Rts. J., 15, 183.

Disney, A. E. (2008). Pray the Devil back to Hell.

Donoho, D. (2006). Human Rights Enforcement in the Twenty-First Century. Ga. J. Int'l \& Comp. L., 35(1), pp. 1-52.

Haider, H. (2013). International Legal Frameworks for Humanitarian Action: Topic Guide (pp. $5-57)$. http://ngocoordination.org/system/files/documents/resources/lib0208_international-legalframeworks-for-humanitarian-action.pdf.

ICC. (n.d.). About the International Criminal Court. About the ICC. http://www.icc-cpi.int/about. 
Ife, J. (2009). Human Rights and Peace. In C. Webel \& J. Galtung (Eds.), Handbook of Peace and Conflict Studies (pp. 160-172). essay, Routledge.

Navarro, K. (2010). Liberian Women Act to End Civil War, 2003. Liberian Women Act to End Civil War, 2003 | Global Nonviolent Action Database. https://nvdatabase.swarthmore.edu/content/liberian-women-act-end-civil-war-2003.

OHCHR. (n.d.). International Human Rights Law. United Nations Human Rights : Office of the High Commissioner. https://www.ohchr.org/EN/ProfessionalInterest/Pages/InternationalLaw.aspx.

Stratton, J. (2020). Hot Topics: Human rights. State Library of NSW. https://legalanswers.sl.nsw.gov.au/hot-topics-human-rights.

Tedla, A. (2011). Tunisians Overthrow Dictator and Demand Political and Economic Reform (JASMINE REVOLUTION), 2010-2011. Tunisians overthrow dictator and demand political and economic reform (Jasmine Revolution), 2010-2011 | Global Nonviolent Action Database.

https://nvdatabase.swarthmore.edu/content/tunisians-overthrow-dictator-and-demand-poli tical-and-economic-reform-jasmine-revolution-201.

UN. (n.d.). About the ICTY. About the ICTY | International Criminal Tribunal for the former Yugoslavia. http://www.icty.org/en/about.

UN. (n.d.). International Court of Justice. United Nations. http://www.un.org/en/model-united-nations/international-court-justice.

UN. (n.d.). Sanctions Security Council. United Nations. https://www.un.org/securitycouncil/sanctions/information. 
UN. (n.d.). United Nations Charter. United Nations. http://www.un.org/en/charter-united-nations/index.html.

UN. (n.d.). Universal Declaration of Human Rights. United Nations. https://www.un.org/en/about-us/universal-declaration-of-human-rights.

Waging War to Keep the Peace: The ECOMOG Intervention and Human Rights. (1993). Human Rights Documents Online, 5(6). https://doi.org/10.1163/2210-7975_hrd-3169-0107. 